\title{
HARRY L. CARRICO AND THE IDEAL OF THE LAWYER-STATESMAN
}

\author{
Wendy C. Perdue *
}

"Professionalism." This is a word that will always be associated with Justice Carrico-not only because he was a consummate professional himself, but also because he was dedicated to assuring that all lawyers understood the full ethical, social, and behavioral implications of their role as lawyers. Under his leadership, Virginia became the first state to require all newly-admitted lawyers to take a day-long course in professionalism. It is a model that has been widely emulated around the country.

Following his retirement from the Supreme Court of Virginia in 2003, Justice Carrico brought his passion for professionalism to the University of Richmond School of Law as our jurist-inresidence. He taught seminars, offered lectures, judged moot court competitions, and held regular office hours just for the sake of talking to students. He understood that in the formation of professional character, it is those one-on-one conversations that can be the most formative.

Justice Carrico's vision of professionalism for lawyers included an obligation to serve the public and so in 2006, he co-chaired a committee charged with designing an implementation strategy for the University of Richmond School of Law's pro bono program. It was the work of that committee that ultimately resulted in the Harry L. Carrico Center for Pro Bono Service. The Carrico Center now oversees one of the most robust pro bono programs in the country, coordinating programs that provide assistance on protective orders for victims of domestic abuse, benefits for disabled veterans, landlord-tenant disputes, immigration, and estate planning for seniors, among other worthy projects. It is a model

* Dean and Professor of Law, University of Richmond School of Law. J.D., 1978, Duke University School of Law; B.A., 1975, Wellesley College. 
program and one that Justice Carrico championed from the outset.

In his book, The Lost Lawyer, Anthony Kronman sketched a vision of professionalism for lawyers-something he called the "lawyer-statesman." According to Kronman, the lawyerstatesman is a person of character and practical wisdom, calm and cautious in demeanor and "able to sympathize with a wide range of conflicting points of view." ${ }^{1} \mathrm{He}$ is someone admired "for his virtue and not just his expertise." Justice Carrico embodied the ideal of the lawyer-statesman. He is an example of professionalism in action that will be hard to replicate, but is one to which we can all aspire.

1. Anthony T. Kronman, The Lost LaWyer 15 (1993).

2. Id. at 16 . 